\title{
KAJIAN KAPASITAS TAMPUNGAN KOLAM RETENSI DI PERUMAHAN SARIMAS, KELURAHAN SUKAMISKIN, KECAMATAN ARCAMANIK, KOTA BANDUNG
}

\author{
An An Anisarida, ST, MT ${ }^{1}$, Bima Lutfi Fuad \\ ${ }^{1,2}$ Teknik Sipil Universitas Winaya Mukti \\ Email: anananisarida@gmail.com ${ }^{1}$, bimalutfi12@gmail.com ${ }^{2}$
}

\begin{abstract}
ABSTRAK
Banjir terjadi karena berkurangnya daerah resapan akibat peningkatan jumlah penduduk, aktivitas dan kebutuhan lahan, baik untuk pemukiman maupun kegiatan ekonomi. Untuk mengatasi banjir, dalam hal ini Kota Bandung membuat kolam retensi yang merupakan salah satu tindakan pencegahan banjir yang ditunjukan untuk mereduksi banjir yang terjadi di kawasan Perumahan Sarimas. Tujuan dari kajian ini yaitu mengkaji Kapasitas Tampungan Kolam Retensi di Perumahan Sarimas, Kelurahan Sukamiskin, Kecamatan Arcamanik, Kota Bandung.

Berdasarkan analisa debit limpasan yang dilakukan dengan kala ulang 10 tahun diperoleh debit maksimum limpasan air menggunakan Metode Hidrograf Satuan Sintetik (HSS) Nakayasu sebesar $20.52 \mathrm{~m}^{3}$. Hasil penelusuran aliran yang telah dilakukan masih menyisakan volume tampungan air yang cukup besar sehingga aliran air keluarnya (outflow) perlu ditambah kapasitasnya yaitu menggunakan pompa berkapasitas $5.01 \mathrm{~m}^{3} / \mathrm{dt}$.
\end{abstract}

Kata-kata kunci: banjir, kolam retensi, metode hss, volume tampungan ,pompa

\begin{abstract}
The flood was triggered by a decrease in absorption zones as population growth, activity and land requirements for housing or economic activities increased. To overcome the flood, Bandung City created a conservation pond as one of the flood prevention measures designated as one of the most frequent flood forest prevention measures in Sarimas. The purpose of this study is to assess of the capacity of the retention pool in Sarimas housing, Sukamiskin sub-district, Arcamanik subdistrict, Bandung city.

Based on a runoff discharge analysis conducted with rain on the 10-year obtained a maximum of water runoff discharge using the method of synthetic hydrograph unit (HSS) Nakayasu of 20.52 $\mathrm{m}^{3}$. The traceability of the flow path carried out still leaves a significant volume of the water tank, with the capacity of the outlet remaining up to $5.01 \mathrm{~m}^{3} / \mathrm{s}$ capacity for the pump.
\end{abstract}

Keywords: flood, conservation pond, hss method, volume of view, pump

\section{PENDAHULUAN}

Pesatnya kegiatan manusia di wilayah perkotaan memberikan dampak positif terhadap kemajuan ekonomi. Namun disisi lain dapat menimbulkan permasalahan lingkungan akibat adanya pembangunan yang kurang memperhatikan daya dukung lingkungannya. Masalah utama yang timbul adalah banjir, genangan air serta penurunan muka air tanah. Banjir dapat terjadi karena berkurangnya daerah resapan akibat meningkatnya jumlah penduduk, aktivitas dan kebutuhan lahan, baik untuk pemukiman maupun kegiatan ekonomi. Kurangnya lahan di perkotaan, sehingga terjadi intervensi kegiatan ekonomi pada lahan yang seharusnya berfungsi sebagai daerah konservasi dan ruang terbuka hijau. Hal ini berdampak pada pendangkalan (penyempitan) sungai, sehingga air meluap dan memicu terjadinya bencana banjir, khususnya pada daerah hilir. Untuk mengatasi banjir, 
dalam hal ini Kota Bandung membuat kolam retensi yang berlokasi di Perumahan Sarimas, Kelurahan Sukamiskin, Kecamatan Arcamanik, Kota Bandung, yang merupakan salah satu solusi untuk mereduksi banjir yang sering terjadi di kawasan Perumahan Sarimas.

\section{TINJAUAN PUSTAKA}

\section{Metode Estimasi Data Curah Hujan Yang Hilang}

Data hujan yang hilang dapat di estimasi apabila di sekitarnya ada stasiun penakar hujan (minimal 2 stasiun) yang lengkap datanya atau stasiun penakar yang datanya hilang diketahui hujan rata-rata tahunannya. (Lily, 2010)

Menghadapi keadaan ini, terdapat dua langkah yang dapat dilakukan yaitu :

1. Membiarkan saja data yang hilang tersebut, karena dengan cara apapun data tersebut tidak akan diketahui dengan tepat.

2. Bila dipertimbangkan bahwa data tersebut mutlak diperlukan maka perkiraan data tersebut dapat dilakukan dengan cara-cara yang dikenal.

Cara "Inversed Square Distance" Persamaan yang digunakan dalam cara "Inversed Square Distance" adalah :

$P_{x}=\frac{\frac{\mathrm{PA}}{\mathrm{d} \cdot \mathrm{A}^{2}}+\frac{\mathrm{PB}}{\mathrm{d} \cdot \mathrm{B}^{2}}+\frac{\mathrm{PC}}{\mathrm{d} \cdot \mathrm{C}^{2}}}{\frac{1}{\mathrm{~d} \cdot \mathrm{A}^{2}}+\frac{1}{\mathrm{~d} \cdot \mathrm{B}^{2}}+\frac{1}{\mathrm{~d} \cdot \mathrm{C}^{2}}}$

Keterangan :

$\mathrm{Px} \quad=$ Curah hujan yang hilang pada stasiun $\mathrm{x}$

PA = Data curah hujan di stasiun sekitarnya pada periode yang sama

d. $A^{2}=$ Jarak Antar Stasiun A,B,C ... dst

$\frac{1}{\mathrm{~d} \cdot \mathrm{A}^{2}}=1$ dibagi antar jarak stasiun $\mathrm{A}, \mathrm{B}, \mathrm{C} \ldots \mathrm{dst}$

\section{Pemilihan Fungsi Distribusi}

Pemilihan fungsi distribusi yang dipakai dalam perhitungan analisis frekuensi berdasarkan nilai parameter statistik dari data lapangan yang cocok atau mendekati sifat khas yang dimiliki oleh fungsi distribusi yang berkaitan, untuk lebih lanjut dapat dilihat dibawah ini :

1. Distribusi Normal

Hampir sama dengan nol $\left(\mathrm{C}_{\mathrm{s}} \approx 0\right)$ dan koefisien kartosis $\mathrm{C}_{\mathrm{k}}=3$.

2. Distribusi Log Normal

Memiliki sifat khas, yaitu asimetrisnya (skewness) $\mathrm{C}_{\mathrm{s}}$ hampir sama dengan 3 dan bertanda positif $(\mathrm{Cs} \approx 3)$. Atau dengan nilai $\mathrm{C}_{\mathrm{s}}$ kira-kira sama dengan tiga kali nilai koefisien variansi $\mathrm{C}_{\mathrm{v}}$.

3. Distribusi Gumbel

Memiliki sifat khas, yaitu nilai $\approx 1,14$ dan koefisien kurtosis $C_{k}=5,4$.

4. Distribusi Gumbel Type I

Memiliki sifat khas, yaitu nilai asimetrinya (skewness) $\mathrm{C}_{\mathrm{s}} \approx 1,1396$, 
sedangkan nilai kartosis $\mathrm{C}_{\mathrm{k}} \approx 5,4002$.

5. Distribusi Log Pearson III Type III

Tidak mempunyai sifat khas yang dapat digunakan untuk memperkirakan jenis distribuís type ini.

Tabel 2.1. Kriteria Penentuan Jenis Sebaran

\begin{tabular}{ll}
\hline \multicolumn{1}{c}{ Jenis Sebaran } & \multicolumn{1}{c}{ Syarat } \\
\hline Normal & $\mathrm{Cs} \approx 0$ \\
Log Normal & $\mathrm{Cs} \approx 3 \mathrm{Cv} . \mathrm{Cs} \geq 0$ \\
Gumbel & $\mathrm{Cs} \approx 1,14 . \mathrm{Ck} \approx 5,4$ \\
Log Perason III & $\begin{array}{l}\text { Cs positif atau negatif dan tidak } \\
\text { memenuhi semua syarat diatas }\end{array}$ \\
\hline
\end{tabular}

Sumber : Soemarto, 1999

\section{Uji Chi-Kuadrat}

Uji chi-kuadrat bertujuan untuk menentukan apakah persamaan distribusi peluang yang telah dipilih dapat mewakili dari distribusi statistik sampel data yang dianalisis. Pengambilan keputusan uji ini menggunakan parameter $\mathrm{x}^{2}$, oleh karena itu disebut dengan uji Chi-Kuadrat.

Adapun kriteria penilaian hasilnya adalah sebagai berikut :

* Peluang lebih dari $5 \%$ maka persamaan distribusi teoritis yang digunakan dapat diterima.

* Ppeluang lebih kecil dari $1 \%$ maka persamaan distribusi teoritis yang digunakan dapat diterima.

* Ppeluang berada diantara $1 \%$ - $5 \%$, maka tidak mungkin mengambil keputusan, perlu penambahan data.

\section{Alternating Block Method (ABM)}

Alternating Block Method (ABM) adalah cara sederhana untuk membuat hyetograph rencana dari kurva IDF (Chow et al., 1988). Hyetograph rencana yang dihasilkan oleh metode ini adalah hujan yang terjadi dalam $\mathrm{n}$ rangkaian interval waktu yang berurutan dengan durasi $\Delta t$ selama waktu $\mathrm{Td}=\mathrm{n} \Delta t$. Untuk periode ulang tertentu, intensitas hujan diperoleh dari kurva IDF pada setiap durasi waktu $\Delta t, 2 \Delta t, 3 \Delta t, \ldots, \mathrm{n} \Delta t$. Ketebalan hujan diperoleh dari perkalian antara intensitas hujan dan durasi waktu tersebut. Perbedaan antara nilai ketebalan hujan yang berurutan merupakan pertambahan hujan dalam interval waktu $\Delta t$. Pertambahan hujan tersebut (blok-blok), diurutkan kembali ke dalam rangkaian waktu dengan intensitas maksimum berada pada tengah-tengah durasi hujan $\mathrm{Td}$ dan blok-blok sisanya disusun dalam urutan menurun secara bolak-balik pada kanan dan kiri dari blok tengah. Dengan demikian terbentuk hyetograph rencana, seperti pada Gambar 2.1. 


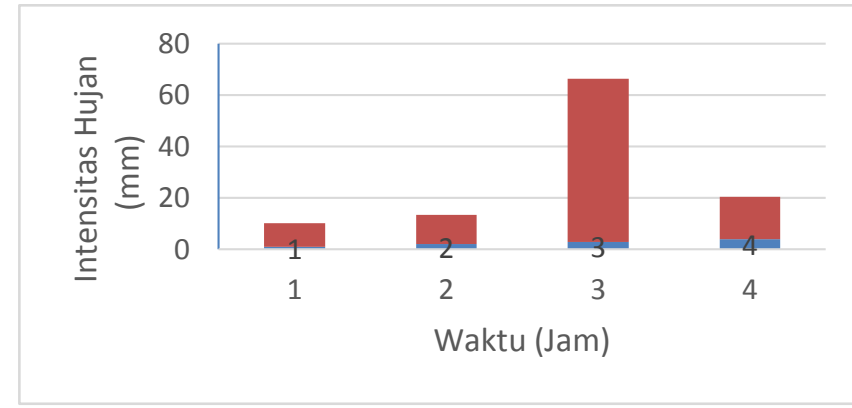

Gambar 2.1 Grafik Hyetograph dengan ABM

Sumber : Chow et al., 1988

\section{Metode Nakayasu}

Hidrograf satuan sintetis Nakayasu dikembangkan berdasarkan beberapa sungai di Jepang (Soemarto, 1987). Penggunaan metode ini memerlukan beberapa karakteristik parameter daerah alirannya, seperti :

1. Tenggang waktu dari permukaan hujan sampai puncak hidrograf (time of peak)

2. Tenggang waktu dari titik berat hujan sampai titik berat hidrograf (time lag)

3. Tenggang waktu hidrograf (time base of hydropraph)

4. Luas daerah aliran sungai

5. Panjang alur sungai utama terpanjang (length of the longest channel)

Bentuk persamaan HSS Nakayasu yaitu :

$Q_{P}=\frac{1}{3.6\left(0.3 t_{p}+t_{0.3}\right)} A R_{o}$

Keterangan :

$\mathrm{Q}_{\mathrm{p}}=$ debit puncak banjir $\left(\mathrm{m}^{3} / \mathrm{dt}\right)$

Ro $=$ hujan satuan $(\mathrm{mm})$

$\mathrm{T}_{\mathrm{p}}=$ tenggang waktu dari permulaan hujan sampai puncak banjir (jam)

$\mathrm{T}_{0.3}=$ waktu yang diperlukan oleh penurunan debit, dari puncak sampai 30\% dari debit puncak (jam)

$\mathrm{CA}=$ luas daerah pengaliran sampai outlet $\left(\mathrm{km}^{2}\right)$

\section{METODOLOGI PENELITIAN}

\section{Lokasi Kajian}

Lokasi kajian merupakan Komplek Perumahan Sarimas yang sering terjadi banjir. Secara Administrasi Perumahan Sarimas berada pada wilayah Kelurahan Sukamiskin, Kecamatan Arcamanik, Kota Bandung seperti tampak pada gambar berikut : 


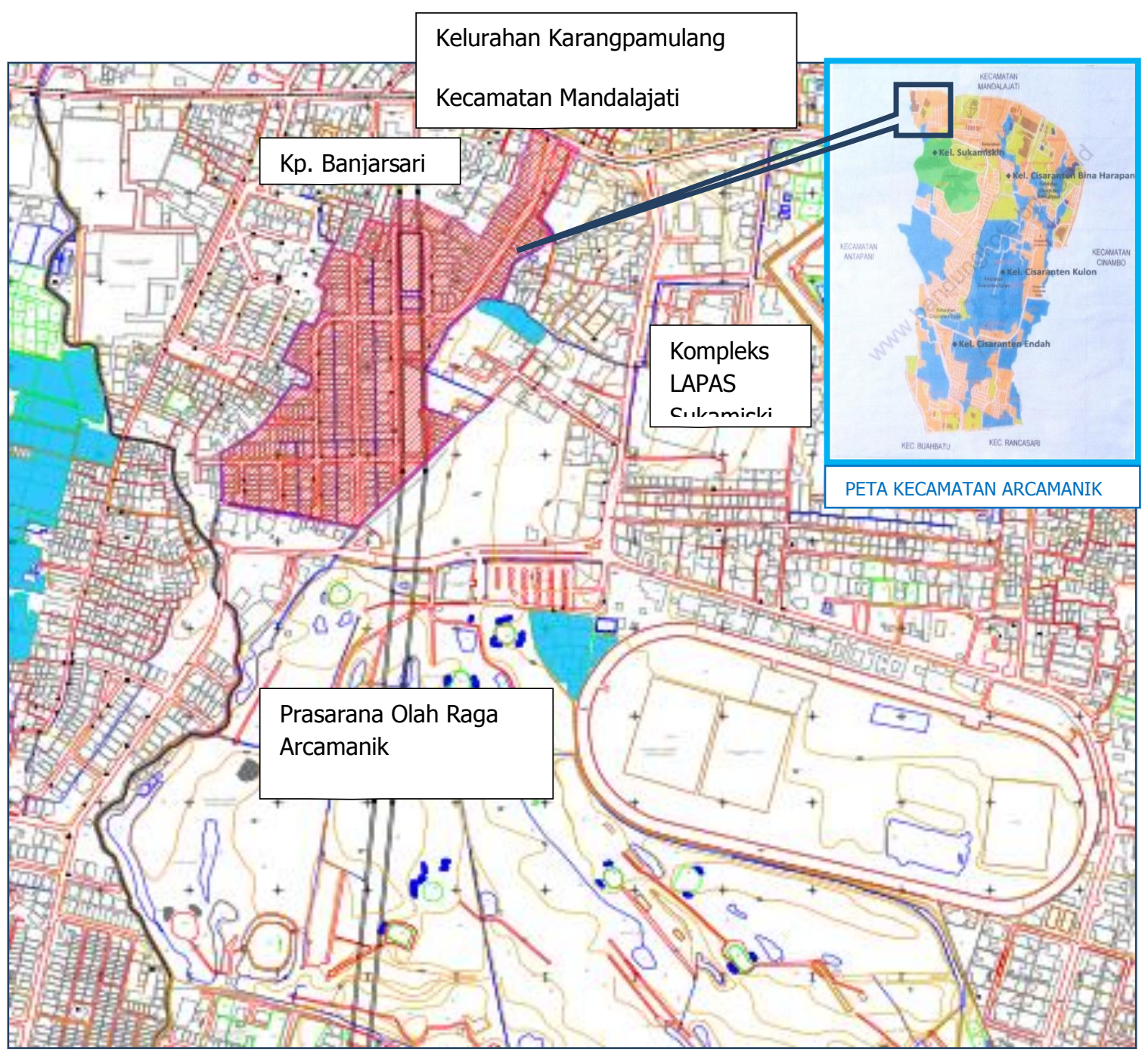

Gambar 3.1 Peta Admnistrasi Kota Bandung

Sumber : Dinas Pekerjaan Umum dan Pengairan Kota Bandung

Secara administrasi, lokasi pekerjaan Perencanaan Kolam

Retensi/Detensi/Resapan I terletak di wilayah :

$>$ Komplek Perumahan Sarimas

> RW 17, Kelurahan Sukamiskin, Kecamatan Arcamanik, Kota Bandung.

\section{Bagan Alir}

Dalam rangka mengkaji kapasitas tampungan kolam retensi dan kapasitas pompadapat di lihat pada bagan di bawah ini : 
Vol 2 No 2 (2021), July 2021, pp. 51-62

(C)2021 Jurnal Teknik Sipil Cendekia

Doi : https://doi.org/10.51988/jtsc.v2i2.36

\section{Proses Kajian}

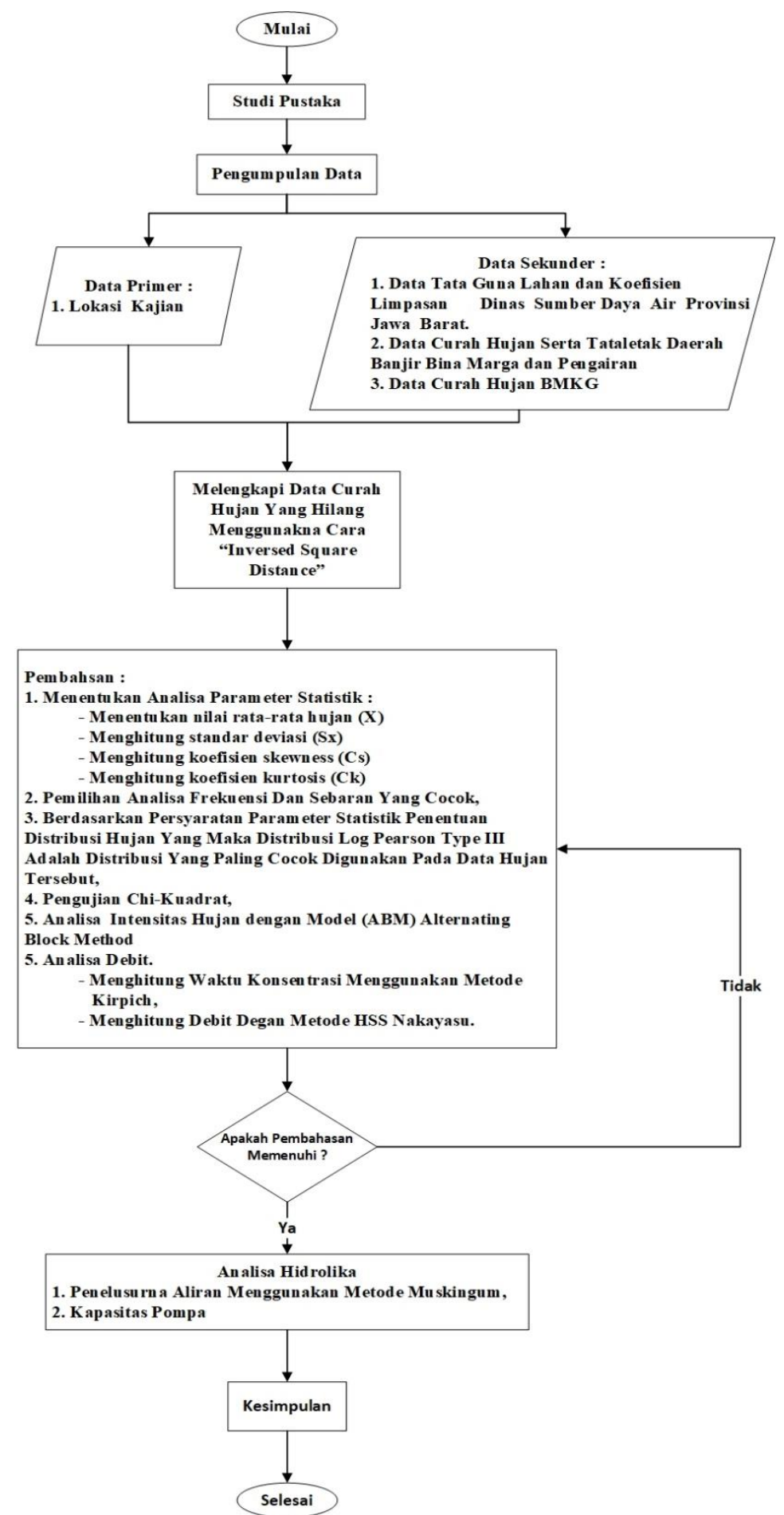

Gambar 3.1 Diagram Alir

Sumber : Hasil Analisa

\section{ANALISIS DAN PEMBAHASAN}

\section{Tinjauan Umum}

Dalam rangka untuk mengetahui kapasitas tampungan kolam dan pompa di 
kolam retensi Sarimas ini, sebagai langkah awal dilakukan pengumpulan data data. Adapun data - data tersebut digunakan sebagai dasar kajian dalam memperoleh analisis dan pembahasan. Dalam analisis dan pembahasan dilakukan Analisis hidrologi dan analisis hidrolika yang menghasilkan debit banjir rencana.

\section{Data Curah Hujan Maksimum}

Berikut adalah tabel data curah hujan harian maksimum selama 10 tahun $(2009 \mathrm{~s} / \mathrm{d}$ 2018) yang diperoleh di Stasiun Cidurian. Stasiun Cidurian sebagai stasiun curah hujan yang terdekat dengan lokasi kajian. Tabel 4.3 Data curah hujan maksimum $\left(\mathrm{CH}_{\mathrm{Max}}\right)$ Stasiun Cidurian.

Tabel 4.1 Data Curah Hujan Maksimum $\left(\mathrm{CH}_{\mathrm{Max}}\right.$ Stasiun Cidurian)

\begin{tabular}{cc}
\hline Tahun & $\begin{array}{c}\mathrm{CH}_{\mathrm{Max}} \\
(\mathrm{mm} / \text { hari })\end{array}$ \\
\hline 2009 & 122 \\
2010 & 92 \\
2011 & 66 \\
2012 & 55 \\
2013 & 70 \\
2014 & 66 \\
2015 & 75 \\
2016 & 120 \\
2017 & 76 \\
2018 & 96 \\
\hline
\end{tabular}

Sumber : Hasil Perhitungan

\section{Analisa Frekuensi dan Pemilihan Sebaran Yang Cocok}

Tabel 4.2 Hasil Penentuan Jenis Sebaran

\begin{tabular}{|c|c|c|c|}
\hline No & Distribusi & Parameter & Kecocokan Parameter \\
\hline 1 & Normal & $\mathrm{C}_{\mathrm{s}} \approx 0$ & Tidak Cocok \\
\hline 2 & Log Normal & $\begin{array}{l}\mathrm{C}_{\mathrm{s}} \approx 3 \mathrm{C}_{\mathrm{v}} \\
\mathrm{C}_{\mathrm{s}} \geq 3\end{array}$ & Tidak Cocok \\
\hline 3 & Gumbel & $\begin{array}{l}\mathrm{C}_{\mathrm{s}} \approx 1.14 \\
\mathrm{C}_{\mathrm{k}} \approx=5.4\end{array}$ & Tidak Cocok \\
\hline 4 & Log Pearson III & $\begin{array}{l}\mathrm{C}_{\mathrm{s}} \text { positif atau negatif dan tidak } \\
\text { memenuhi semua syarat diatas }\end{array}$ & Cocok \\
\hline
\end{tabular}

Sumber : Hasil Perhitungan 


\section{Uji Chi-Kuadrat}

Tabel 4.3 Pengujian Chi-Kuadrat

\begin{tabular}{rccccc}
\hline \multirow{2}{*}{ Kelas } & Nilai Batas Tiap Kelas & \multirow{2}{*}{ Ei } & Oi & $(\text { Ei-Oi })^{\wedge} 2$ & $(\text { Ei-Oi })^{\wedge} 2 / \mathrm{Ei}$ \\
\cline { 2 - 3 } & $(\mathrm{mm})$ & 2.5 & 4 & 2.25 & 0.9 \\
1 & $>91.38$ & 2.5 & 0 & 6.25 & 2.5 \\
2 & $82.97-91.38$ & 2.5 & 2 & 0.25 & 0.1 \\
3 & $75.19-82.97$ & 2.5 & 4 & 2.25 & 0.9 \\
4 & $65.98-75.19$ & 10 & 10 & 11 & 4.4 \\
\hline
\end{tabular}

Sumber : Hasil Perhitungan

\section{Analisa Intensitas Hujan Metode ABM}

Tabel 4.4 Analisis Intensitas Hujan Jam - Jaman Metode ABM

\begin{tabular}{|c|c|c|c|c|c|c|c|c|}
\hline \multirow{3}{*}{$\begin{array}{c}\mathrm{Td} \\
\text { jam }\end{array}$} & \multirow{3}{*}{$\begin{array}{c}\Delta \mathrm{t} \\
\mathrm{jam}\end{array}$} & \multirow{3}{*}{$\begin{array}{c}\text { It } \\
\mathrm{mm} / \mathrm{jam}\end{array}$} & \multirow{3}{*}{$\begin{array}{c}\mathrm{X}=\mathrm{It} \\
\mathrm{Td} \\
\mathrm{mm}\end{array}$} & \multirow{3}{*}{$\begin{array}{l}\Delta \mathrm{X} \\
\mathrm{mm}\end{array}$} & \multirow{3}{*}{$\begin{array}{c}\Delta X \\
\%\end{array}$} & \multirow{2}{*}{\multicolumn{2}{|c|}{ hyetograph }} & \multirow{3}{*}{$\begin{array}{c}\mathrm{Xe}=\mathrm{X} \\
\mathrm{C} \\
(\mathrm{mm})\end{array}$} \\
\hline & & & & & & & & \\
\hline & & & & & & \multicolumn{2}{|c|}{$(\%) \quad(\mathrm{mm})$} & \\
\hline 1.00 & 1.00 & 46.40 & 46.40 & 46.40 & 63.29 & 9.06 & 11.99 & 6.46 \\
\hline 2.00 & 1.00 & 29.16 & 58.33 & 11.93 & 16.27 & 11.39 & 15.08 & 8.12 \\
\hline 3.00 & 1.00 & 22.23 & 66.68 & 8.35 & 11.39 & 63.29 & 83.82 & 45.13 \\
\hline 4.00 & 1.00 & 18.33 & 73.32 & 6.64 & 9.06 & 16.27 & 21.54 & 11.60 \\
\hline \multicolumn{4}{|c|}{ Jumlah } & 73.32 & 100.00 & 100.00 & 132.44 & 71.32 \\
\hline
\end{tabular}

Sumber : Hasil Perhitungan

Adapaun grafik distribusi hujan jam-jaman hasil analisis yang dilakukan dengan metode ABM dapat dilihat pada gambar grafik 4.1.

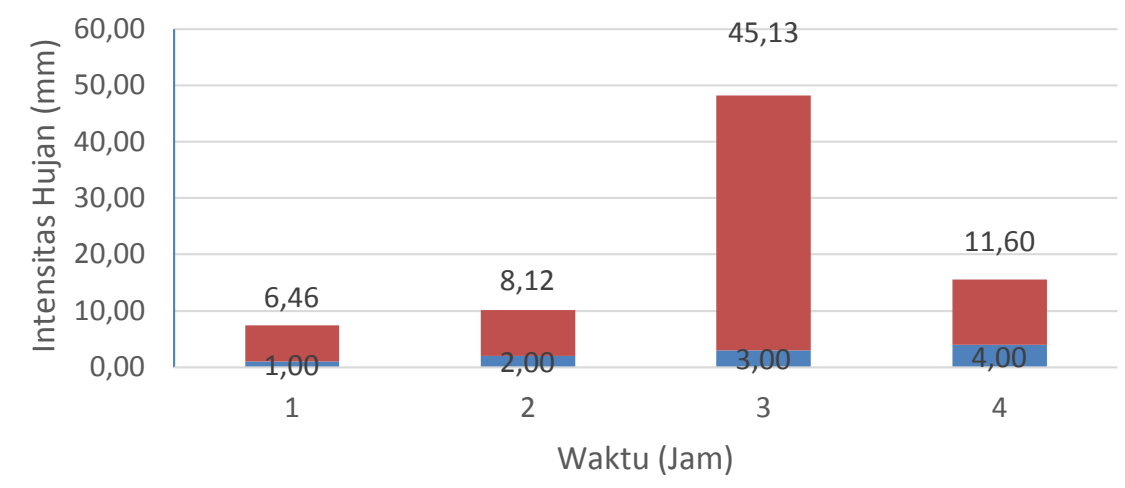

Gambar 4.1 Grafik Distribusi Hujan Efektif Jam - Jaman Metode ABM Sumber : Hasil Perhitungan 


\section{Analisa Debit}

Berdasakan analisis debit hidrograf limpasan hujan hasil analisis yang dilakukan dengan Metode HSS Nakayasu dapat diperlihatkan dalam bentuk sebuah grafik yang dapat dilihat pada gambar 4.2.

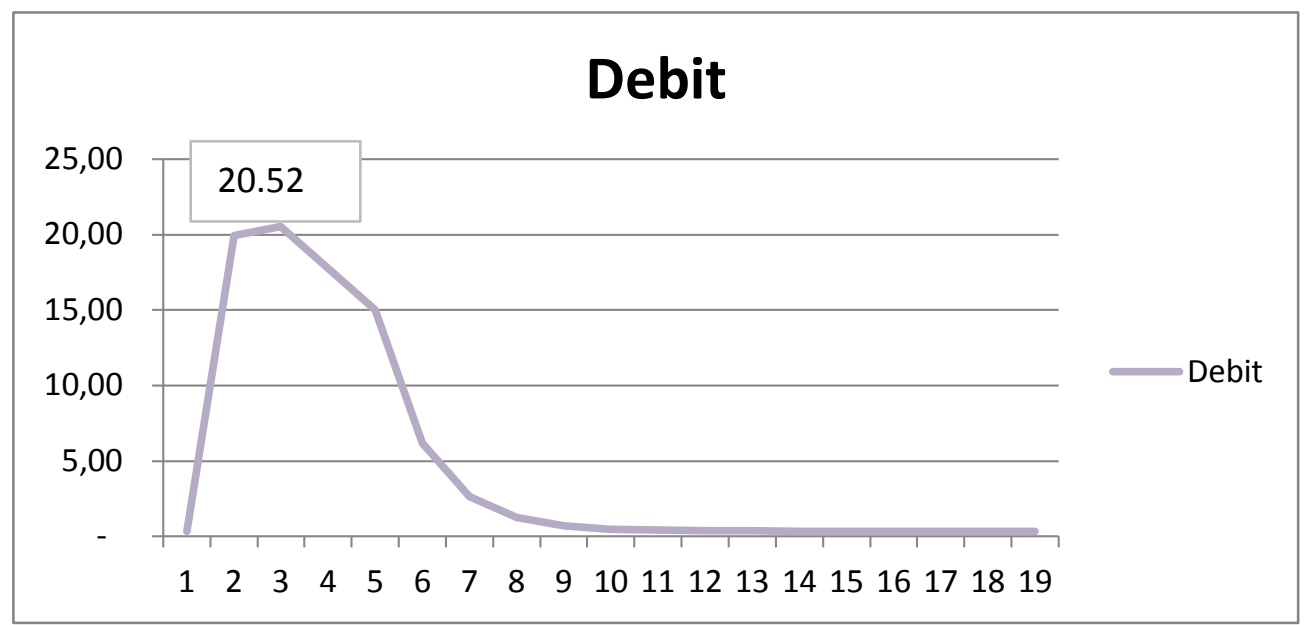

Gambar 4.2 Grafik Debit Total Hidrograf Limpasan Metode HSS Nakayasu

Sumber : Hasil Perhitungan

\section{Penelusuran Aliran}

Berdasarkan hasil analisis penelusuran aliran yang telah dilakukan dapat ditampilkan debit air masuk (inflow) dan debit air keluar (outflow) yang terjadi sehingga dapat

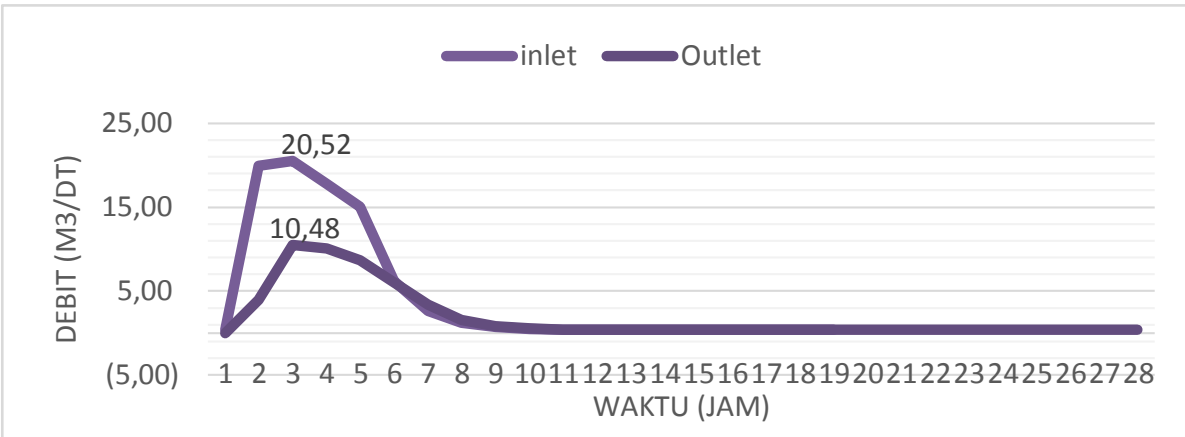

digambarkan dalam bentuk grafik seperti berikut.

Gambar 4.3 Grafik Outflow dan Inflow Penelusuran Aliran HSS Nakayasu Sumber : Hasil Perhitungan

Hasil perhitungan volume kolam dan kapasitas pompa yang digunakan adalah sebagai berikut :

Pompa $5.01 \mathrm{~m}^{3} /$ detik. 


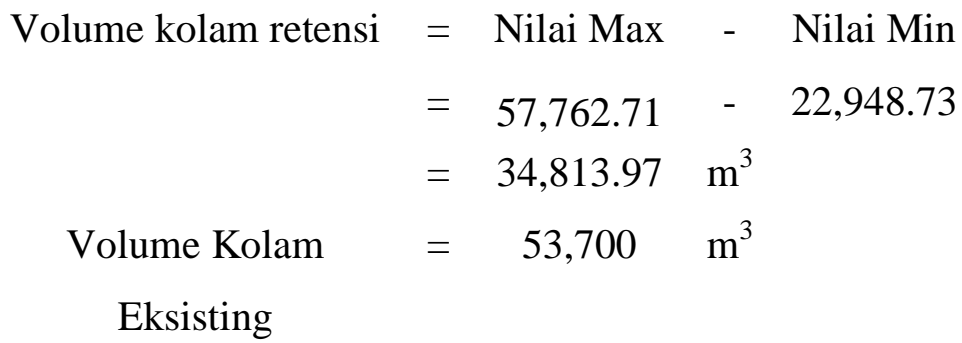

Berdasakan analisis volume aliran air keluar yang telah dilakukan seperti pada tabel diatas, nilai volume air pada pompa digunakan analisis menggunakan pompa dengan kapasitas $5.01 \mathrm{~m}^{3} /$ detik dimana pada kajian yang dilakukan menggunakan 1 buah pompa yaitu pompa durasi pemompaan hingga 4 jam.

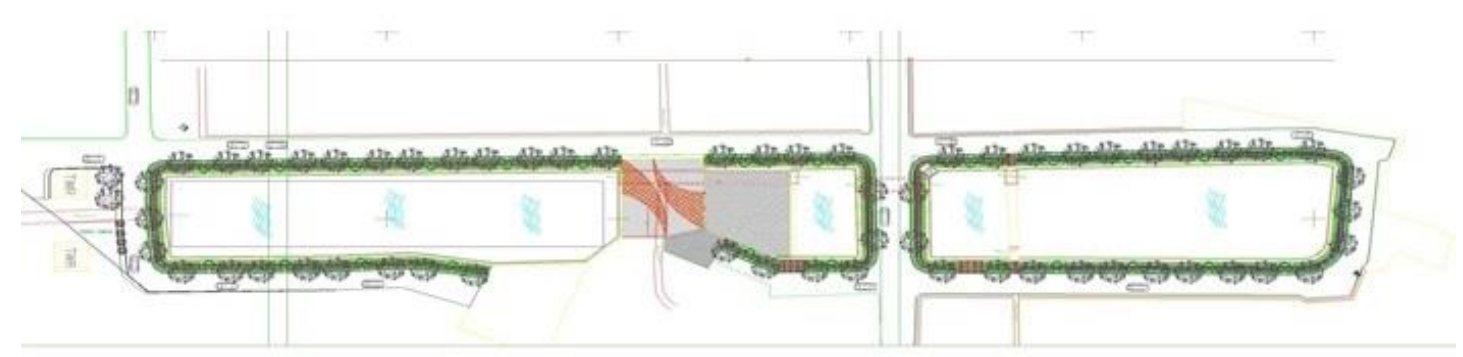

Gambar 4.4 Gambar Sketsa Kolam Retensi

Sumber : Hasil Perhitungan

\section{KESIMPULAN}

Berdasarkan kesimpulan hasil Kajian Kapasitas Tampungan Kolam Retensi Di Perumahan Sarimas, Kelurahan Sukamiskin, Kecamatan Arcamanik, Kota Bandung dapat disimpulkan :

1. Berdasarkan analisa debit yang dilakukan dengan hujan kala ulang 10 tahun diperoleh debit maksimum limpasan air menggunakan Metode Hidrograf Satuan Sintetik (HSS) Nakayasu yaitu sebesar $20.52 \mathrm{~m}^{3}$

2. Berdasarkan penelusuran aliran yang sudah dihitung diperoleh kapasitas kolam tampungan maksimum yaitu $72,167.37 \mathrm{~m}^{3}$.

3. Hasil penelusuran aliran yang telah dilakukan masih menyisakan volume tampungan air yang cukup besar yang dapat mengakibatkan masih terjadi bajir di areal permukiman, sehingga perlu ditambah kapasitas keluar (outflow) air dari kolam retensi dengan menggunakan pompa.

4. Pada kolam retensi dihasilkan variasi volume kolam retensi dan kapasitas pompa sebagai berikut : 
- Pompa dengan debit $5.01 \mathrm{~m}^{3} /$ detik dengan volume kolam retensi sebesar 57,762.71 $\mathrm{m}^{3}$ dengan durasi 5 jam.

\section{DAFTAR PUSTAKA}

Anisarida, A. A., (2017). Evaluasi Kondisi Permukaan Jalan Dengan Metode Road Condition Index (RCI). GEOPLANART, 1(2), 13-21.

Anisarida, A. A., Prima, G. R., \& Janizar, S. (2020). PREFERENSI KEMUDAHAN PENGGUNAAN SEPEDA MOTOR DI KOTA BANDUNG. Akselerasi, 2(1).

Anisarida, A. A., \& Janizar, S. J. (2020). Besaran Biaya Korban Kecelakaan Sepeda Motor di Kota Bandung. GEOPLANART, 2(2), 62-74.

Assidiq, Muh, Abdullah \& Rahman, Abd. (2019). Prediksi Nilai Debit Puncak Menggunakan Metode Muskingum Di Sungai Pasangkayu Kecamatan Pasangkayu Kabupaten Pasangkayu, Vol. 18 No. 1 Januari - Juni (2019).

Badan Meteorologi, Klimatologi, Dan Geofisika, 2019. Data Curah Hujan Tahun 2009-2018. Kota Bandung.

Bedient, P.B. And Huber, W.C. (1992) Hydrology And Floodplain Analysis. Addison-Wesley, Reading, Mass.

Chow, V. T., Maidment, D. R. \& Mays, 1988. Applied Hydrology. New York: Mc. Graw-Hill Book Company.

Dinas Bina Marga Dan Pengairan, 2019. Data Curah Hujan Tahun 2009-2018 Dan Data Tata Letak Daerah Banjir. Kota Bandung.

Dinas Sumber Daya Air Provinsi Jawa Barat (2019) Data Tata Guna Lahan Dan Koefisien Limpasan. Kota Bandung.

Hilman Taufik, 2016. Evaluasi Kinerja Kolam Retensi Di Taman Lansia Kota Bandung - Jawa Barat

Lily, Lm. 2010. Hidrologi Praktis.Lubuk Agung, Bandung.

R.K. Linsley, M.A. Kohler And J.L.H. Paulus ,1958. Hydrology For Engineers. New York : Mcgraw Hill.

Siregar,H.T, 2017. Analisa Perhitungan Dimensi Saluran Irigasi Bendungan Sei Padang Daerah Irigasi Bajayu Kab. Serdang Berdagai. Medan.

Soemarto, C.D. 1987. Hidrologi Teknik. Surabaya: Usaha Nasional.

Soemarto, C.D. 1999, Hidrologi Teknik, Penerbit Erlangga, Jakarta.

Soewarno, 1995. Hidrologi Aplikasi Metode Statistik Untuk Analisa Data. Bandung: Nova.

Soewarno. (2000). Hidrologi Operasional (Jilid Kesatu). PT. Citra Aditya Bakti. Bandung. 
Sosrodarsono Suyono \& Kensaku Takeda, 1993, Hidrologi Untuk Pengairan, Pt. Pradnya Paramitha, Jakarta.

Sri Harto. Br. 1993. Analisis Hidrologi. Jakarta : Gramedia Pustaka Utama.

Taufik, Hilman (2016) Evaluas Kinerja Kolam Retensi Di Taman Lansia Kota Bandung - Jawa Barat.

Tikno, Sunu (2002) Penerapan Metode Penelusuran Banjir (Flood Routing) Untuk Program Pengendalian Dan Sistem Peringatan Dini Banjir Kasus : Sungai Ciliwung. Jurnal Sains \& Teknologi Modifikasi Cuaca, Vol. 3, No. 1, P.53-6.

Triatmodjo, Bambang, 2006. Hidrologi Terapan. Yogyakarta: Beta Offset Yogyakarta.

Triatmodjo, Bambang, 2008. Hidrologi Terapan. Yogyakarta: Beta Offset Yogyakarta. 